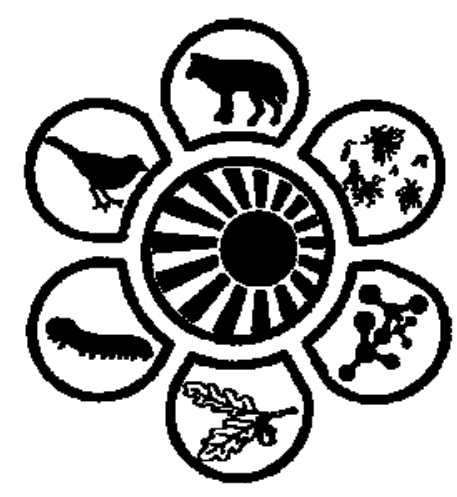

Вісник Дніпропетровського університету. Біологія, екологія.

Vìsnik Dnìpropetrovs'kogo unìversitetu. Seriâ Bìologiâ, ekologiâ

Visnyk of Dnipropetrovsk University. Biology, ecology.

Vìsn. Dnìpropetr. Unìv. Ser. Bìol. Ekol. 2014. 22(2), 145-150.

doi: $10.15421 / 011420$

ISSN 2310-0842 print

ISSN 2312-301X online

www.ecology.dp.ua

УДК 581.1.03+631.531.173

\title{
Дослідження функціонального стану рослин під час імпульсної світлової стимуляції
}

\author{
Д.В. Чернетченко, М.П. Моцний, Н.П. Боцьва, О.В. Єліна
}

Дніпропетровський національний університет імені Олеся Гончара, Дніпропетровськ, Украӥна

Контроль розвитку рослин у штучних умовах - досить актуальна проблема на сьогоднішній день, при цьому реєстрація біоелектричних потенціалів, що генерує листя рослини, залишається найадекватнішим способом оцінки та діагностики функціонального стану рослини. Важливу роль відіграє можливість безперервного та автоматизованого контролю параметрів підтримання життєдіяльності. У даній роботі використано апаратно-програмний комплекс автоматизованої системи реєстрації біоелектричних потенціалів на базі USB-пристрою з подальшою обробкою оцифрованих сигналів на ПК. Запропоновано універсальну схему реєстрації біопотенціалів, яка дозволяє проводити експериментальні дослідження впливу на досліджуваний об'єкт фотостимуляції. Засобами комплексної автоматизованої системи зафіксовано біоелектричні потенціали з поверхні листка перцю у відповідь на світлові стимули. Упродовж дослідів змінювалися два головні параметри: довжина хвилі та інтенсивність освітлення. Охарактеризовано отриману динаміку викликаних біопотенціалів, а також кількісно оцінено рівень інтенсивності та характер освітлення, при якому спостерігається найбільша та найменша чутливість до інтенсивності освітлення. На базі отриманих експериментальних даних визначено можливі механізми та математичні параметри процесів, що лежать в основі генерації світлоіндукованих потенціалів.

Ключові слова: реєстрація біоелектричних потенціалів; автоматизація фізичного експерименту; математична модель клітини; біопотенціали листя перцю; світлоіндуковані біопотенціали

\section{Research of the plant's functionality state during pulsed light stimulation}

\author{
D.V. Chernetchenko, M.P. Motsnyj, N.P. Botsva, O.V. Elina \\ Oles Honchar Dnipropetrovsk National University, Dnipropetrovsk, Ukraine
}

Effective and controlled plants development in artificial conditions today represents an urgent problem. Registration of bioelectrical potentials of the plants is still the best way of evaluation and diagnostics of the physiological functionality state of the biosystem. Very important role is played by an opportunity of continuous and automated control of parameters of vital activity support. This work employs hardware and software system for automated recording of bioelectrical potentials on the basis of USB-device with subsequent processing of signals on PC. We proposed the universal pattern of bioelectrical potentials' recording which allowed to detect the response of the biological object to photo-stimulation. It can be used for the deeper understanding and investigation of biological mechanisms of electrical potentials' generation in cells. During the experiments, we change two main parameters: the wavelength and intensity of light. System for bioelectrical potentials' recording consists of hardware and software parts. Integrated system of recording and biometrical processing was used for analysis of the leaves' electrical responses to photo stimuli. The dynamics of these potentials was studied, with the quantitative analysis of intensity of light level, where we obtained the minimum and maximum of sensitivity to the light intensity. As a result of modeling, we determined that electrical response of cells to photo-stimulation was based on selective conductivity of cell membrane for $H^{+}$ions. Therefore, we showed the biophysical relation of plant light-induced potentials to the intracellular biophysical mechanisms.

Keywords: bioelectrical potentials' recording; automated physical experiment; mathematical cell model; light-induced biopotentials

Дніпропетровський начіональний університет ім. Олеся Гончара, пр. Гагаріна, 72, Дніпропетровськ, 49010, Украӥна Oles Honchar Dnipropetrovsk National University, Gagarin Ave., 72, Dnipropetrovsk, 49010, Ukraine

Tel.: +38-050-420-86-04.E-mail: rakon3@gmail.com 


\section{Вступ}

Сучасні методи електрофізіологічної діагностики життєдіяльності рослин поки що перебувають на стадії експериментальних розробок, але зацікавленість цими методами зростає все більше, у міру того, як з'являється необхідність вирощування рослин у штучно створених умовах. Оптимізація умов вирощування ставить важливе завдання безперервного контролю розвитку рослин та підтримання нормальних процесів їх життєдіяльності.

Для виконання цього завдання найдоцільніше оцінювати біоелектричні показники, які реєструються 3 різних органів рослин. Сучасні електровимірювальні методи здатні забезпечити контактну або дистанційну реєстрацію біопотенціалів із подальшою математичною обробкою отриманих результатів. Головною проблемою $\epsilon$ визначення ефективних у діагностичному відношенні біоелектричних показників і встановлення їх відповідності процесам життєдіяльності рослин. Для цього застосовували світлоіндуковані електростимуляції (ЕС) зеленої поверхні рослин, зокрема листя. Це пов'язано з тим, що життєдіяльність рослин зумовлена фотосинтезом i, за відсутності хлорофілу та сформованого апарату хлоропластів, ЕС не спостерігається зовсім. Іншою суттєвою перевагою ЕС у діагностичному плані є досить низький поріг їх виникнення, у середньому, він становить 23 лк, що на порядок нижче за компенсаційний вплив фотосинтезу (Hit et al., 1972).

Інтерес до світлозалежних біоелектричних потенціалів зумовлений не тільки перспективою їх використання для діагностичних цілей. Особливої уваги потребує питання щодо функціональної ролі рослинних біоелектричних потенціалів. Зважаючи на це, необхідно визначити, чи $є$ світлозалежні зміни електричних потенціалів листка рослини фізіологічним наслідком фотосинтезу, або це, безпосередньо, електрофізіологічна функція. Раніше було зроблено припущення (Skulachev et al., 1972), що енергетична роль біопотенціалів не обмежується дією мембран органел клітини, які беруть участь у генеруванні клітинної енергії, а також $\epsilon$ універсальним шляхом енергозабезпечення біосистем. Наведена функція біопотенціалів у рослинних тканинах може бути досить важливою для організації життєдіяльності рослинного організму.

\section{Матеріал і методи досліджень}

Для дослідження біоелектричних потенціалів рослин застосовано універсальну автоматизовану установку реєстрації біопотенціалів рослин (Chernetchenko et al., 2013). Дослідження проводили на добре розвинених проростках перцю (сорт «Дарунок Молдови» in vivo). Застосована методика дозволила проводити експерименти на одній і тій самій рослині, у серії експериментів реєстрацію проводили на одній і тій самій ділянці листа, що значно зменшує помилку отриманих даних.

Блок вимірювання (1) містить екрановану камеру для дослідженого об'єкта та електроди ЕВЛ-1М, що не поляризуються (рис. 1). Блок реєстрації (2) забезпечує можливість одночасного надходження підсиленого сигналу на самописець Endim і на вхід пристрою оцифрову- вання даних із подальшою обробкою у ПК. Для калібрування самописця застосовано підсилений сигнал синусоїдальної форми частотою 1 Гц від калібратора. Оцифровування даних здійснювали двоканальним USB-осцилографом IRIS iз частотою дискретизації 100 Гц, при цьому похибка вимірювань складала не більше ніж 2-3\% у будь-якому 3 досліджуваних діапазонів вхідного сигналу. USBосцилограф дозволяв проводити вимірювання та запис сигналу протягом декількох десятків годин.

Листок рослини, пророщений у горщику із землею, розташовували в екранованій камері на активній поверхні фотостимулятора зі спеціальним тепловим фільтром для максимального зменшення теплового впливу. У центрі світлової плями розташовували активний неполяризувальний електрод, пасивний електрод на неосвітленій частині листа. Між електродами упродовж експерименту реєстрували різницю потенціалів.

Тривалість світлового імпульсу задавали за допомогою реле часу. Освітленість регулювали за допомогою сили струму через фотостимулятор, значення якого контролювали за допомогою цифрового міліамперметра. Освітленість вимірювали люксметром Ю-116.

Фотостимулятор (3) містить блок світлодіодів чотирьох кольорів: білого, синього $(\lambda=470$ нм), зеленого ( $\lambda=$ $540 \mathrm{Hм})$, червоного ( $\lambda=690$ нм). Для зменшення нагрівання досліджуваного об'єкта під час фотостимуляції світлодіоди закривали спеціальним інфрачервоним фільтром. Освітленість, створену діодами, регулювали силою струму в них, контролювали фотометром. Розроблена схема системи реєстрації $\epsilon$ універсальною, вона дозволяє проводити експериментальні дослідження біопотенціалів в умовах світлової стимуляції за різних значень інтенсивності освітлення та зміни довжини хвилі світла.

Обробку, аналіз і подальшу візуалізацію зареєстрованих у процесі експерименту оцифрованих біопотенціалів проводили оригінальними програмними засобами. Для поєднання USB-осцилографа 3 персональним комп'ютером розроблено універсальний драйвер пристрою. Окрема програма забезпечує автоматичне збереження у пам'яті отриманих у цифровому форматі через USB-порт ПК даних про динаміку зміни потенціалу у відповідних файлах формату *.dat.

Клієнтська частина програмного забезпечення розроблена на базі візуального середовища програмування LabView (Ogren and Jones, 2006). У вікні клієнтської програми відбувається представлення та кількісний аналіз отриманих даних. Програма також дозволяє визначати та зберігати у базі даних експерименту такі головні показники зареєстрованих сигналів як амплітуди піків холодових (теплових або інших) потенціалів із відповідними часовими відмітками; відсоткові співвідношення амплітуд піків відведених потенціалів, що характеризують динаміку перебігу процесу; поточні налаштування часових i амплітудних параметрів для калібрування та кількісної оцінки отриманих сигналів та візуалізації шкал графічної залежності «потенціал - час».

Статистичний аналіз масивів отриманих даних та визначення параметрів математичної моделі проводили 3 використанням математичного пакета Matlab. 


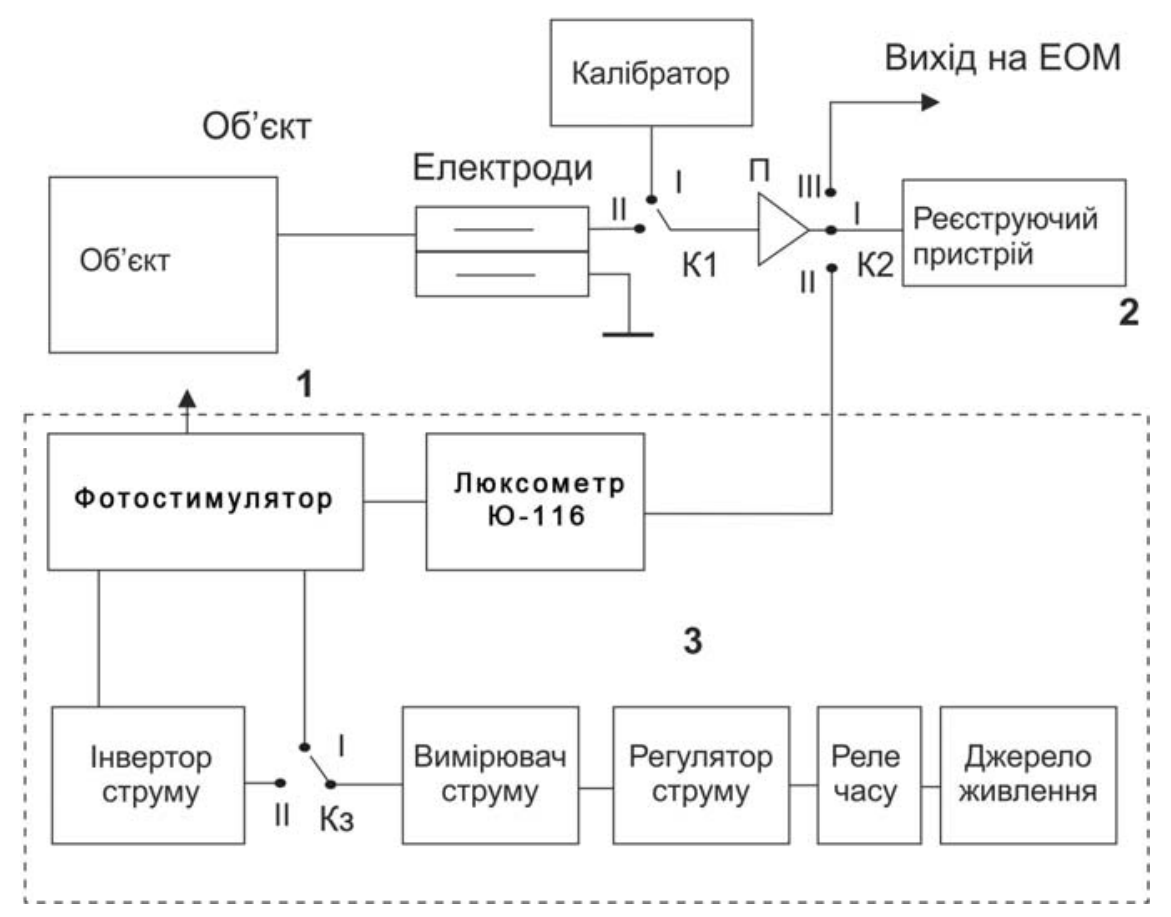

Рис. 1. Блок-схема системи ресстрації біоелектричних потенціалів:

1 - блок вимірювання; 2 - блок реєстрації, 3 - блок фотостимуляції; П - підсилювач; К1, К2, К3- перемикачі

\section{Результати та їх обговорення}

За допомогою автоматизованої системи реєстрації біоелектричних потенціалів досліджено вплив фотостимуляції на біоелектричну реакцію листя кукурудзи за методикою, описаною Davies (2004). При цьому здійснено як цифровий запис і програмну обробку зареєстрованих потенціалів, так і їх фіксацію на самописці для контролю та порівняння. Запис біопотенціалів рослини у відповідь на ритмічне холодове подразнення («одиночний світловий імпульс») без застосування згладжувального фільтра за даними з вікна клієнтської програми на ПК наведено на рисунку 2.

У першій серії дослідів спостерігали світлоіндуковані потенціали, викликані одиночними світловими стимулами тривалістю $\mathrm{t}_{1}=30$ с. Його аналіз показує, що одиночні світлові подразнення викликають чітко виражені деполяризаційні потенціали. На рисунку $2 a$ наведено біопотенціали, викликані стимуляцією листка синім світлом із довжиною хвилі $\lambda_{1}=475$ нм змінної інтенсивності. На рисунку $2 a$ освітленість (I) становила $\mathrm{I}_{1}=$ 50 лк. За вказаної освітленості зареєстровано потенціали дзвоноподібної форми, загальною тривалістю близько 55 с і середньою амплітудою 6 мВ. За збільшення освітленості удвічі динаміка суттєво не змінюється, амплітуда збільшується в середньому до 8 мВ.

У разі застосування для стимулювання зеленого світла 3 довжиною хвилі $\lambda_{2}=550$ нм (рис. 2 б). Форма потенціалів відповіді зберігається, але при цьому значно зменшуються амплітуда та тривалість відповіді. За освітлення листка червоним світлом із довжиною хвилі $\lambda_{3}=700$ нм і малою інтенсивністю $\mathrm{I}_{1}=50$ лк потенціали практично не реєструються. За збільшення освітленості до $\mathrm{I}_{2}=100$ лк спостерігаються потенціали тривалістю до 40 с й амплітудою до 4 мВ.
За результатами проведеної серії експериментів побудовано графіки залежності середньої амплітуди отриманих потенціалів від довжини хвилі стимулювального світла (рис. 3). Виходячи 3 отриманої залежності для біопотенціалів мембрани, можна зробити висновок, що максимальна деполяризація спостерігається як для малих, так i для великих значень інтенсивності випромінювання в області найкоротших довжин хвиль випромінювання $\left(\lambda_{1}=475\right.$ нм). У зеленій області спектра деполяризація значно знижується $\left(\lambda_{2}=550 \mathrm{Hм}\right)$, а у червоній $\left(\lambda_{3}=700 \mathrm{Hм}\right)$ рівень деполяризації залежить від інтенсивності стимуляції.

Після налаштування фільтра запис електричних відповідей від електродів із поверхні рослини повторювали 20 разів для отримання заданої точності вимірювання. За результатами окремих експериментів із вивчення впливу фотостимуляції, збережених у файлах бази даних, спеціальною програмою комплексу розраховано необхідні значення та побудовано графік залежності середньої амплітуди отриманих потенціалів від довжини хвилі стимулювального світла (рис. 3).

Отримані із застосуванням автоматизованого програмно-апаратного комплексу результати у цілому добре узгоджуються з результатами попередніх експериментів iз реєстрації потенціалів листя кукурудзи під час термічної стимуляції, отриманими за допомогою лише аналогових пристроїв (Davies, 2004). Перевірка відповідності отриманих в експерименті та оброблених цифрових даних записам, одночасно зафіксованим самописцем, свідчить про високу точність роботи автоматизованої системи. Похибка, що накопичується через обмеження вимірювального USB-пристрою та наявність зовнішніх завад, перебуває в допустимих межах 2-5\% і практично не впливає на характеристики вихідного сигналу. 

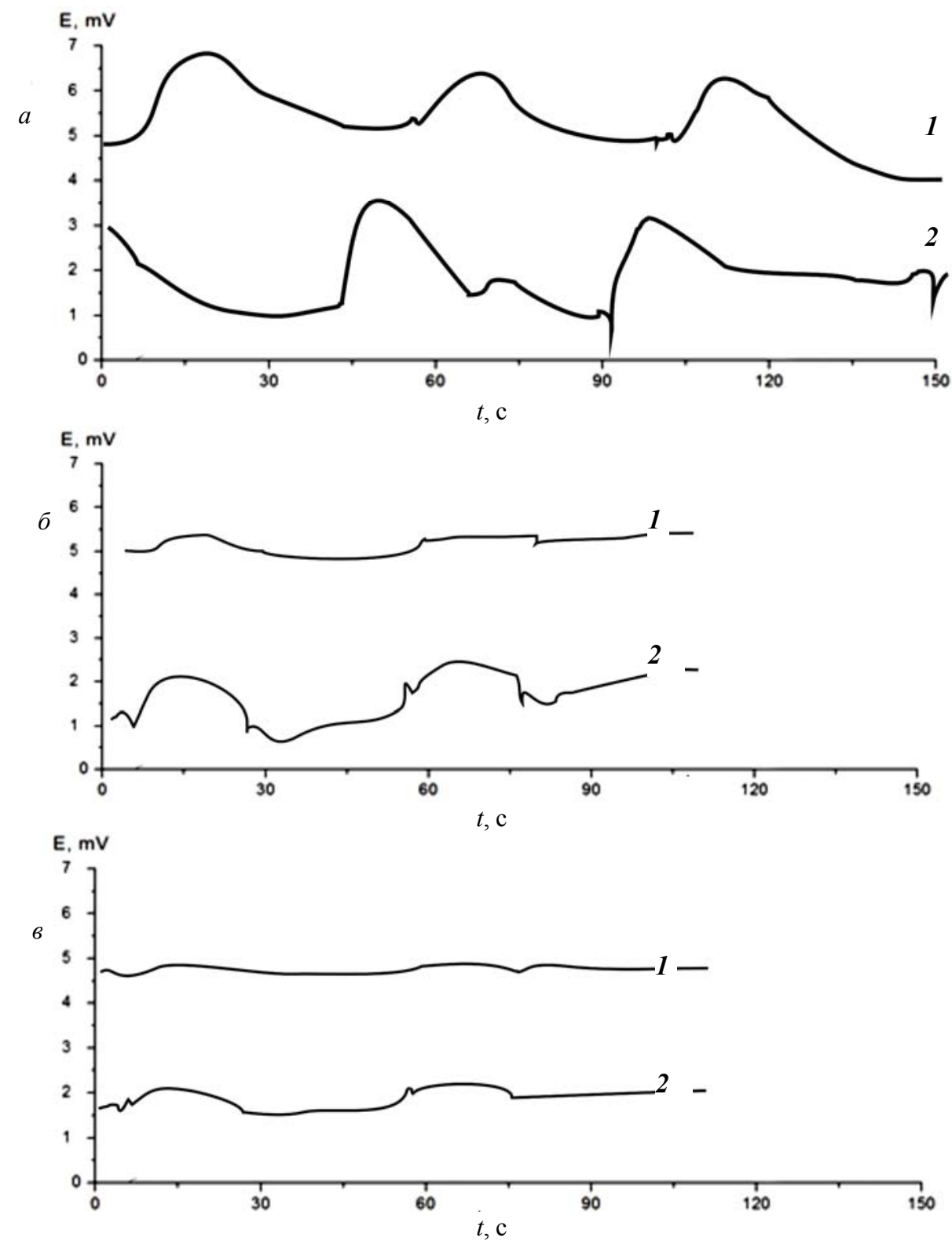

Рис. 2. Електричні потенціали листя перцю під час одиночної світлової стимуляції тривалістю 30 с: $a$ - світлом із довжиною хвилі $\lambda_{1}=475 \mathrm{HM}, \sigma-\lambda_{2}=550 \mathrm{Hм}, 6-\lambda_{3}=700 \mathrm{HM}$; I - освітленість $\mathrm{I}_{1}=50$ лк, II - освітленість $\mathrm{I}_{2}=100$ лк

Для аналізу можливих внутрішньоклітинних механізмів виникнення та динаміки зареєстрованих біоелектричних потенціалів розроблено математичну модель клітини зі здатністю генерації активних електричних потенціалів. Запропоновано пояснення механізму утворення електричної реакції перцю на світло, пов'язане із сумарним потоком іонів водню $H^{+}$із зовнішнього середовища у клітину. Виникнення потоку $H^{+}$після короткого імпульсу освітлення може бути зумовлене низкою факторів: збільшенням швидкості пасивного потоку $H^{+}$до цитоплазми, гальмуванням активного транспорту $\mathrm{CO}_{2}$ із середовища в темнових реакціях фотосинтезу, а також можливістю поглинання світла хлоропластами 3 наступною активацією іонних каналів $H^{+}$та подальшою зміною $p H$ на поверхні клітини.

Для опису динаміки іонних струмів $I_{H}$ та потенціалу на мембрані $V_{m}$ під час світлового стимулювання на основі трансмембранного транспорту застосовано формулу:

$$
I_{H}\left(V_{m}, t\right)=\left(V_{m}-E_{H}\right) g_{H},
$$

де $E_{H}$ - потенціал рівноваги іонних каналів $H^{+}, g_{H}-$ електрична провідність каналів.

Зміни загального мембранного потенціалу описуються рівнянням із моделі Ходжкіна - Хакслі (Hodjkin et al., 1952):

$$
\frac{d E_{M}}{d t}=\frac{1}{C} \sum i_{r}, r \in\left(K^{+}, C l^{-}, H^{+}, C a^{2+}\right)
$$

де $E_{M}-$ мембранний потенціал, $i_{r}-$ густина струму через мембрану іона сорту $r, C$ - питома ємність мембрани.

Системи первинного (протонна й кальцієва АТФази) і вторинного $\left(2 \mathrm{H}^{+} / \mathrm{Cl}^{-}\right.$- симпортер і $\mathrm{H}^{+} / \mathrm{K}^{+}$- антипортер) транспорту описуються як системи, які можуть перебувати у двох станах (вільному та зв'язаному з іоном). Потік через них знаходиться як стаціонарний розв'язок системи рівнянь:

$$
j_{r}^{P}=E_{0} \frac{k_{+1} k_{+2}-k_{-1} k_{-2}}{k_{+1}+k_{-1}+k_{+2}+k_{-2}},
$$


де $E_{0}$ - загальна концентрація ферменту, $k_{+1}, k_{-1}, k_{+2}, k_{-2}-$ константи прямих (+) і зворотних (-) переходів у вільний стан з іоном $\left(k_{+1}, k_{-1}\right)$ і пов'язане 3 іоном - вільний $\left(k_{+2}, k_{-2}\right)$ стан. Для протонної помпи $k$ описується рівняннями (4):

$$
\left\{\begin{array}{l}
k_{+1}=k_{1}\left[H^{+}\right]_{i n}, \\
k_{-1}=k_{1} \exp \left(-\square G_{A T \Phi}\right), \\
k_{+2}=k_{2} \frac{F E_{M}}{R T} \frac{1}{1-\exp \left(-\frac{F E_{M}}{R T}\right)}, \\
k_{-2}=k_{2}\left[H^{+}\right]_{\text {out }} \frac{F E_{M}}{R T} \frac{\exp \left(-\frac{F E_{M}}{R T}\right)}{1-\exp \left(-\frac{F E_{M}}{R T}\right)},
\end{array}\right.
$$

де $k_{1}$ й $k_{2}-$ не залежні від мембранного потенціалу та концентрації протонів константи, $\left[H^{+}\right]_{\text {in }}$ i $\left[H^{+}\right]_{\text {out }}$ концентрації протонів у цитоплазмі й апопласті, $\Delta G_{A T \Phi}-$ енергія, що звільняється під час гідролізу АТФ.

Система реєстрації потенціалів дозволяє визначати параметри моделі, що характеризують характер генерації потенціалу на мембрані клітини у реальному часі із застосуванням апроксимації вхідних даних значень потенціалів рослини.

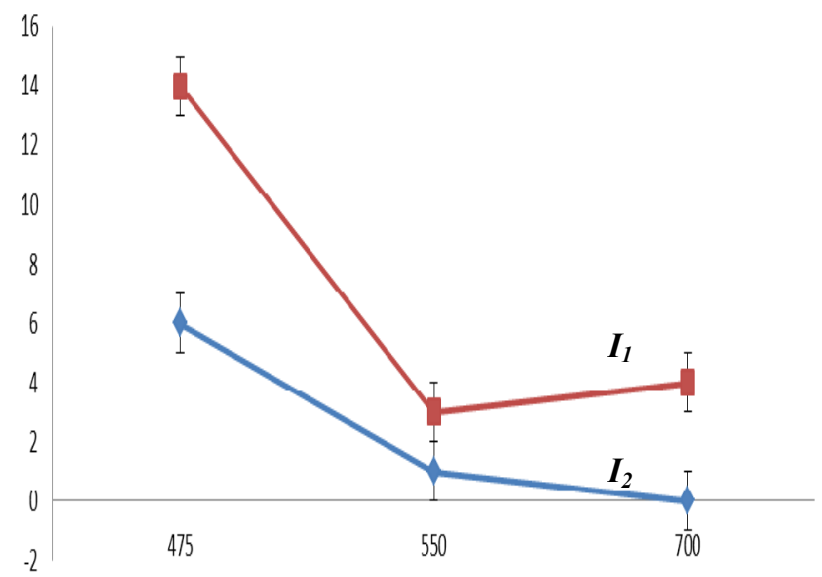

Рис. 3. Залежність амплітуди біопотенціалів від довжини хвилі стимулювального світла при одиночній імпульсації за освітленості 50 ( $\left.\mathrm{I}_{1}\right)$

та 100 (I $\left.\mathbf{I}_{2}\right)$ лк: по осі абсцис довжина хвилі $\lambda$ (нм), по осі ординат - амплітуда потенціалу А (мB)

Відношення концентрацій іонів $H^{+}$визначали за зміною трансмембранного потенціалу, виходячи 3 рівняння (4), та обчислювали за експериментальними даними у середовищі математичного пакета Matlab. Для отриманих експериментальних даних провідність іонних каналів мембрани клітин дорівнювала $g_{H}=32,5$, що близько до теоретичних значень провідності протонних каналів рослин. Це достатньо достовірно вказує на походження зареєстрованих потенціалів. Періодичні дзвоноподібні відповіді, що спостерігалися в експериментах (рис. $2 a, \sigma, в), \epsilon$ активною електричною відповіддю клітини на подразник - потенціали дії, в основі яких лежить транспорт іонів $H^{+}$. Деяке відхилення розрахованих під час моделювання електричних провідностей від табличних значень для відповідних іонів спостерігається через наявність у клітині струмів інших типів, а також пасивного струму витоку іонів із клітини.

\section{Висновки}

Для підвищення ефективності методик електрофізіологічної діагностики стану та розвитку рослин під час безперервного прижиттєвого контролю показників їх життедіяльності використовували розроблену автоматизовану систему реєстрації та обробки біопотенціалів із застосуванням сучасних комп'ютерних технологій. Універсальний апаратно-програмний комплекс реєстрації біоелектричних потенціалів на базі USB-пристрою 3 подальшою обробкою оцифрованих сигналів на ПК дозволяє проводити експериментальні дослідження в умовах змінної фотостимуляції (зміна інтенсивності та довжини хвилі). Програма забезпечує фільтрацію зовнішніх перешкод, візуалізацію, кількісний аналіз і збереження отриманих результатів у базі даних.

Завдяки проведеній серії експериментів із вивчення світлоіндукованих потенціалів рослин установлено: за меншої інтенсивності (50 лк) деполяризаційні потенціали не реєструються, за більшої (100 лк) - виникають деполяризаційні потенціали амплітудою 4 мВ, що суттєво перевищує рівень деполяризації, викликаної зеленим світлом.

Аналізуючи отримані дані, слід відмітити загальний вигляд біопотенціалів, індукованих світловими імпульсами: вони мають коротку латентну фазу світлоіндукованої реакції, яка, за сучасними даними, характеризує активність фотохромної системи (Lyalin et al., 1967), після чого настає фаза деполяризації та, нарешті, глибока та тривала фаза гіперполяризації (Motsnij et al., 2004).

Отримані результати показують, що головні відмінності CE закінчуються, в основному, фазою деполяризації. Викликає інтерес той факт, що головні відмінності параметрів початкової фази $\mathrm{CE}$ спостерігаються в червоній області спектра та значною мірою залежать від значення освітленості.

Засобами комплексної автоматизованої системи виконано реєстрацію та обробку визваних біоелектричних потенціалів листя перцю у відповідь на світлові стимули. За результатами кількісного аналізу динаміки отриманих потенціалів установлено оптимальні параметри освітлення для ефективного стимулювання та підтримання розвитку рослини. Ці результати можуть бути застосовані для регулювання спектрального складу світла під час вирощування рослин в умовах штучного освітлення.

Для аналізу можливих внутрішньоклітинних механізмів виникнення та динаміки зареєстрованих біоелектричних потенціалів розроблено математичну модель клітини зі здатністю генерації активних електричних потенціалів. У результаті визначення параметрів моделі встановлено, що в основі електричної відповіді клітини на фотостимули лежить селективна зміна електричної провідності клітинної мембрани для іонів $H^{+}$. Установлено зв'язок між потенціалами активності, що реєструвалися з поверхні рослини, та внутрішньоклітинними процесами. 


\section{Бібліографічні посилання}

Chernetchenko, D.V., Motsnyj, M.P., Botsva N.P., Elina, E.V., 2013. Avtomitizovana systema reestraciy bioelectrichnih potencialiv [Automated experiment fot bioelectrical potentials registration]. Vìsn. Dnìpropetr. Unìv. Ser. Bìol. Ekol. 21(2), 70-75 (in Ukrainian).

Motsnyj, M.P., Elina, E.V., Vlasova, S.V., 2004. Issledovanie reakcii rasteniy, vizvannoi ritmicheskoy stimulyaciei [The study plants responses induced by repetitive stimulation]. Nauka ta osvita, Odessa, 55, 37-38 (in Russian).

Hit, O., 1972. Fotosintez [Photosynthesis]. Mir, Moscow (in Russian).

Skulachev, V.P., 1972. Transformaciya energii v biomembranah [Transformation of energy in biological membranes]. Nauka, Moscow (in Russian).

Lyalin, O.O., 1967. Biojelektricheskie perehodnye processy, voznikajushhie v liste rastenij pri svetovom vozdeistvii [Bioelectric transients occurring in plant leaves with light vozdeistvii]. Kibernetika $\mathrm{v}$ rastenievodstve. Izd-vo VINGUSH MOX SSSR (in Russian).

Davies, E., 2004. New functions for electrical signals in plants. New Phytol. 161, 607-610.

Davies, E., 1987. Action potentials as multifunctional signals in plants - a unifying hypothesis to explain apparently disparate wound responses. Plant Cell Environ. 10, 623-631.

Eccles, J., 1966. Fiziologiia sinapsov [Physiology of synapses]. Mir, Moscow (in Russian).

Friesen, W.O., Friesen, J.A., 1994. NeuroDynamix: Computer models for neurophysiology. Oxford University Press, New York.
Goldman, D.E., 1943. Potential, impedance, and rectification in membranes. J. Gen. Physiol. 27(1), 37-60.

Hodgkin, A.L., Huxley, A.F., 1952. A quantitative description of membrane current and its application to conduction and excitation in nerve. J. Physiol. 117, 500-544.

Hoppensteadt, F.C., 1986. An introduction to the mathematics of neurons. Cambridge University Press, Cambridge.

Hille, B., 2001. Ionic channels of excitable membranes. Sinauer Associates, Sunderland.

Huguenard, J., McCormick, D.A., 1994. Electrophysiology of the neuron: An interactive neuron. Oxford University Press, Oxford.

Heldt, H.W., 1997. Plant biochemistry \& molecular biology. Oxford University Press, Oxford.

Koch, C., Segev, I., 1989. Methods in neuronal modeling: From synapses to networks. Bradford Book, The MIT Press, Cambridge.

Lysikov, V.N., 2001. Studying some features of maize genetics and developmental biology using electrophysiological techniques. Action potentials in maize sieve tubes change phloem translocation. J. Exp. Bot. 45(4), 463-469.

Muyskens, M.A., Glass, S.V., Wietsma, T.W., Gray, T.M., Mark, A., 2007. Data acquisition in the chemistry laboratory using LabVIEW software. J. Chem. Educ. 73(12), 1112-1114.

Ogren, P.J., Jones, T.P., Paul, J., 2006. Laboratory interfacing using the LabVIEW software package. J. Chem. Educ. 73(12), 1115-1116.

Надійшла до редколегії 11.10.2014 